\title{
STUDI PENGGUNAAN ABU BATU SEBAGAI BAHAN SUBTITUSI PASIR PADA PEMBUATAN GENTENG BETON TERHADAP KUAT LENTUR GENTENG BETON
}

Drs. Hendri Dunant Hamidi, M.Si dan Elmarini, S.Pd.

\begin{abstract}
The purpose of this study is to investigate the strength value of concrete pentile using stone ashes as the sand substitutional material at persentation degrees of $0 \%, 5 \%, 10 \%$ and $15 \%$. The research was conducted at Balai Penelitian Bahan Dinas Industri on Jl. Let. Jend. Suprapto and the making of concre the congrete partile was Conducted at PD. Patria Factory on J. Narogong Raya Bantar Gebang Bekasi from February to April 2002. Using an experiment methode wite four substitutional treatment of $0 \%, 5 \%, 10 \%$ and 5 $\%$, there were is pieces of pentile being used for each treatment, ten for strength difraction test and five for water absorption test. The result of the study showed that concrete pentile type A (0 \%) had $197 \mathrm{~kg} / \mathrm{cm}^{2}$ diffraction strength with $9.24 \%$ water absorption at avarange : type $B(5 \%)$ had 201 $\mathrm{kg} / \mathrm{cm}^{2}$ diffraction strength with $9.25 \%$ water absorption at avarage : Type C (10\%) $187 \mathrm{~kg} / \mathrm{cm}^{2}$ diffraction strength with $11.02 \%$ water absoprtion at averange : Type D (15\%) had $172 \mathrm{~kg} / \mathrm{cm}^{2}$ diffraction strength with $14.10 \%$ water absorption at averange. The data of the study was tested using statifical test with $\alpha=0,01$ one tail, variant analysis. Based on the analysis we abstained $t_{\text {hitung }}=21.59$ which is bigger than $t_{\text {tabel }}=4$.38. Ho was in regretion area. So, there was a signtificant difference at the stone ashes substitution to the value of concrete pentile espesialy at $10 \%$ substitutional. In summary, it can be concluded that the higer the presentation of stone ashes being used, the lower the strength of the concrete pentile is.

Kata Kunci : abu batu, genteng beton, kuat lentur.
\end{abstract}

\footnotetext{
Studi Penggunaan Abu Batu Sebagai Bahan Subtitusi Pasir Pada Pembuatan Genteng Beton Terhadap Kuat Lentur Genteng Beton ( Hendri Dunant Hamidi, Dosen Jurusan Teknik Sipil FT- UNJ.)
} 


\section{Pendahuluan}

Sejalan dengan kegiatan pembangunan di bidang perumahan yang setiap tahun terus meningkat, maka kebutuhan bahan bangunan terus meningkat pula, diantaranya adalah bahan penutup atap. Berbagai macam bahan penutup yang dapat kita jumpai di pasaran, baik bentuk, jenis, tipe maupun cara pewarnaan yang dapat kesemuanya itu untuk memenuhi kebutuhan atau selera pemakainya. Jenis bahan dan bentuk penutup atap juga dapat dibedakan menjadi beberapa jenis misalnya, genteng keramik, seng gelombang, asbes gelombang, genteng beton dan lain-lain.

Genteng beton adalah unsur bangunan yang dibuat dari campuran bahan-bahan semen portland, agregat halus, air dengan atau tanpa bahan pembantu lain, dibuat sedemikian rupa sehingga dapat digunakan untuk bahan penutup atap.

Genteng beton mempunyai kelebihan tersendiri karena dibuat dari bahan baku pasir dan semen. Di samping dapat dibuat bermacam-macam bentuk yang beraneka ragam, juga perubahan bentuk akibat pengembangan dan penyusutan relatif kecil, maka kerapihan dalam pemasangan tentu akan lebih baik sehingga kemungkinan tampias waktu hujan akan relatif kecil.

Bahan yang sangat mempengaruhi mutu genteng beton adalah bahan pembentuknya yaitu pasir. Pasir yang baik adalah agregat yang keras dan kuat serta ulet kekuatannya melebihi semen portland setelah mengeras. Syarat mutu yang dibutuhkan agregat adalah agregat halus bersih, kekal, keras dan kuat, kebersihan dan kemurnian agregat ini sangat penting karena bila pasir banyak mengandung lumpur dan zat-zat organik lainnya akan membuat adukan menjadi jelek dan akan mempengaruhi kekuatannya.

Pasir merupakan bahan bangunan yang sangat penting untuk pembuatan genteng beton, khususnya di jakarta mempunyai harga yang relatif mahal. Oleh karena itu penulis tertarik untuk mencoba menggunakan abu batu sebagai bahan substitusi agregat halus pada pembuatan genteng beton. Dalam hal ini guna untuk mendapatkan bahan yang murah dan bermutu baik dengan cara mencari bahan-bahan lain selain yang sudah digunakan.

Abu batu adalah butiran mineral keras yang bentuknya mendekati bulat MENARA, JURNAL TEKNIK SIPIL VOL. I, NO. 2 JULI 2006: 172-181 
atau berupa hasil desintegrasi batu-batuan dari alat pemecah batu. Umumnya butirannya lebih banyak halus dibandingkan dengan pasir dan ukurannya berkisar antara 0,075 $\mathrm{mm}$ sampai $5 \mathrm{~mm}$.

Sifat fisik abu batu :

Dari hasil pengujian dilaboratorium abu batu mempunyai analisa fisik sebagai berikut :

1. Warna $=$ hitam kecoklat-coklatan

2. Berat Isi $=1,585$

3. Absorsi air rata-rata $=4,745 \%$

4. Fine modulus/kehalusan butiran $=3,32$

5. Kadar Lumpur $=0,4 \%$

6. Test kandungan organik dengan larutan $\mathrm{NaOH} 3 \%$ zat warna larutan adalah jernih.

7. Apparent Specific Gravity rata-rata $=2,705 \mathrm{gr}$

8. Bulk Specific Gravity kondisi kering rata-rata $=2,25 \mathrm{gr}$

9. Kadar air $=4,04 \%$.

Abu batu dapat dijadikan sebagai bahan alternatif dari pasir beton yang biasa digunakan pada pembuatan genteng beton, di mana saat ini sedang krisis moneter harga pasir beton sangat mahal sehingga macetnya industri-industri pembuatan genteng yang ada.

\section{Metode Penelitian}

Penelitian ini menggunakan metode eksperimen di loboratorium yang meliputi 4 macam perlakuan untuk kelompok benda uji genteng beton yang menggunakan abu batu sebagai bahan substitusi agregat halus, untuk kemudian dicari yang terbaik.

Penelitian ini juga diharapkan akan menghasilkan variasi kelompok nilai kuat lentur genteng beton substitusi abu batu.

Disain penelitian yang digunakan digambarkan sebagai berikut:

$$
\begin{array}{lll|}
\hline \text { E1 } & \mathrm{X} 1 & \mathrm{C} 1 \\
\hline
\end{array}
$$


Keterangan :

$\mathrm{E} 1$ = kelompok benda uji

$\mathrm{X} 1$ = perlakuan yang diberikan

$\mathrm{C} 1$ = hasil uji

Prosedur Penelitian

Prosedur penlitian yang digunakan meliputi tiga tahap yaitu: pekerjaan persiapan, pemeriksaan bahan dan pekerjaan pembuatan benda uji.

1. Pekerjaan Persiapan

Pekerjaan persiapan meliputi pekerjaan persiapan dan penggadaan bahanbahan yang akan digunakan untuk pengujian, yaitu : pasir, semen dan abu batu.

2. Pemeriksaan Bahan

Pemeriksaan bahan dilakukan terhadap pasir diketahui sifat-sifat dari bahan tersebut.

3. Pembuatan benda uji

Pembuatan benda uji genteng beton dengan perbandingan berat pada campuran 1 semen : 2 pasir, sedangkan abu batu sebagai bahan substitusi pasir alam digunakan variasi pencampuran $0 \%, 5 \%, 10 \%$, dan $15 \%$.

Setelah dilakukan rencana perbandingan campuran dan bahan telah dipersiapkan, maka dilakukan pencampuran diaduk dengan molen menjadi adukan yang homogen, dimasukkan ke dalam cetakan kemudian ditekan dengan mesin pres.

Sebelum adukan dimasukkan ke dalam cetakan terlebih dahulu alat pencetakan bagian atas diberi pelumas oli yang telah dipanaskan sebelumnya, kemudian untuk bagian bawah alat pencetak diberi kain penyaring, kain ini dimaksudkan untuk membantu fungsi lubang-lubang yang terdapat pada pelat dasar dalam mengurangi jumlah air yang keluar pada saat pengepresan.

Untuk pencetakan genteng ini digunakan cara basah maka pada pengepresan air yang berlebihan dalam adukan akan keluar sehingga genteng yang baru dicetak tersebut memperoleh kekakuan. Setelah itu cetakannya dilepas dengan cara memindahkan presan genteng di atas tatakan genteng, 
pelepasan genteng dilakukan dengan hati-hati, selanjutnya genteng yang telah diberi tatakan diletakkan di atas rak-rak penyimpanan.

Penyusunan genteng beton di rak-rak itu diatur sedemikian rupa sehingga genteng tidak lembab udara dan terlindungi oleh udara, tiupan angin dan matahari selama 24 jam. Pada saat penyimpanan dirak itu merupakan proses curing/ pematangan tahap pertama.

Selanjutnya untuk tahapan curing kedua, genteng diambil dari rak penyimpanan dan direndam selama tiga hari. Setelah itu diangkat dari bak perendam, kemudian genteng diangin-anginkan dalam tempat lembab selama 28 hari. Hal ini berarti genteng telah mengalami curing tahap ketiga, setelah 28 hari genteng beton tersebut telah siap diuji.

\section{Hasil Penelitian}

Pada penelitian telah dilakukan beberapa perlakuan terhadap benda uji. Untuk kelompok A adalah genteng beton tanpa menggunakan substitusi pasir abu batu (0\%), kelompok $\mathrm{B}$ dengan substitusi $5 \%$ abu batu, kelompok $\mathrm{C}$ dengan substitusi $10 \%$ abu batu dan kelompok D dengan substitusi pasir abu batu $15 \%$.

Selanjutnya penilaian dilakukan terhadap benda uji, pada pengujian ukuran, daya serap air, kerapatan air dan kuat lentur, secara lengkap hasil penelitian dapat dilihat sebagaimana tabel berikut :

Tabel 1. Hasil Pengujian Genteng Beton

\begin{tabular}{|l|c|c|c|c|c|l|}
\hline No. & $\begin{array}{c}\text { Sa } \\
\mathrm{mpe} \\
\mathrm{I}\end{array}$ & $\begin{array}{c}\text { Berat } \\
(\mathrm{Kg})\end{array}$ & Tebal $(\mathrm{mm})$ & $\begin{array}{c}\text { Kuat } \\
\text { Lentur } \\
\left(\mathrm{Kg} / \mathrm{cm}^{2}\right)\end{array}$ & $\begin{array}{c}\text { Daya } \\
\text { Serap Air } \\
(\mathrm{Kg})\end{array}$ & Kerapatan Air \\
\hline 1. & A & 4496 & 12,35 & 197 & 9,26 & Tidak rembes \\
\hline 2. & B & 4720 & 12,4 & 201 & 9,52 & Tidak rembes \\
\hline 3. & C & 4685 & 12,33 & 189 & 11,02 & Tidak rembes \\
\hline 4. & D & 4585 & 12,47 & 172 & 14,01 & Tidak rembes \\
\hline
\end{tabular}

Dari tabel di atas dapat dilihat bahwa pemakaian abu batu pada pembuatan genteng beton tidak begitu pengaruh terhadap beratnya, hal ini dapat dilihat dari berat rata-rata genteng beton dimana selisih berat masingStudi Penggunaan Abu Batu Sebagai Bahan Subtitusi Pasir Pada Pembuatan Genteng Beton Terhadap Kuat Lentur Genteng Beton ( Hendri Dunant Hamidi, Dosen Jurusan Teknik Sipil FT- UNJ.) 
masing kelompok benda uji tidak begitu jauh. sedangkan hasil kuat lentur pada tabel di atas maka hasil pengujian terlihat bahwa perlakuan A lebih rendah dari perlakuan $\mathrm{B}$, perlakuan $\mathrm{B}$ lebih tinggi dari perlakuan $\mathrm{C}$ dan perlakuan $\mathrm{C}$ lebih tinggi dari perlakuan $\mathrm{D}$.

Menurut SNI 03-0096-1999 daya serap air untuk setiap genteng beton tidak lebih dari 10\%. Dari tabel di atas didapat bahwa nilai daya serap air dengan penambahan abu batu tidak memenuhi standar karena melebihi 10\% dari yang disyaratkan sedangkan hasil pengujian daya serap air genteng beton diperoleh dari hasil pengujian untuk tiap perlakuan. Hasil pengujian kerapatan air untuk perlakuan $A, B, C$ dan $D$ tidak rembes, sehingga dapat dipakai. Menurut SNI-03-0096-1999 menyatakan bahwa apabila genteng basah tetapi tidak terjadi tetesan air maka dinyatakan tahan terhadap perembesan air.

\section{Uji Normalitas}

Analisa statistik yang digunakan untuk menguji normalitas data adalah menggunakan Uji Lilliefours. Data yang dianalisa adalah data nilai kuat lentur genteng beton dari masing-masing kelompok perlakuan yaitu perlakuan $A$ (0\%), B (5\%), C (10\%) dan D (15\%).

\section{a. Uji Normalitas Data Kuat Lentur Genteng Beton Untuk Perlakuan A} (campuran $0 \%$ pasir abu batu).

Hasil pengujian normalitas dari data nilai kuat lentur genteng beton dengan persentase substitusi pasir abu batu $0 \%$ menghasilkan $L_{0}=0,2133$, pada taraf signifikan $(\alpha)=0,01$ diperoleh nilai $L=0,2940$, dengan kriteria pengujian apabila $\mathrm{L}_{0}<\mathrm{L}$ maka data berdistribusi normal dengan demikian dapat disimpulkan bahwa populasi kelompok A berdistribusi normal.

\section{b. Uji Normalitas Data Kuat Lentur Genteng Beton Untuk Perlakuan B} (campuran $5 \%$ pasir abu batu).

Hasil pengujian normalitas dari data nilai kuat lentur genteng beton dengan persentase substitusi pasir abu batu $5 \%$ menghasilkan $L_{0}=0,2398$, pada taraf signifikan $(\alpha)=0,01$ diperoleh nilai $L=0,2940$, dengan kriteria pengujian apabila $L_{0}<L$ maka data berdistribusi normal (lihat lampiran 16, $h$. 
76), dengan demikian dapat disimpulkan bahwa populasi kelompok B berdistribusi normal.

\section{c. Uji Normalitas Data Kuat Lentur Genteng Beton Untuk Perlakuan C (campuran $10 \%$ pasir abu batu).}

Hasil pengujian normalitas dari data nilai kuat lentur genteng beton dengan persentase substitusi pasir abu batu $10 \%$ menghasilkan $L_{0}=0,2664$, pada taraf signifikan $(\alpha)=0,01$ diperoleh nilai $L=0,2940$, dengan kriteria pengujian apabila $\mathrm{L}_{0}<\mathrm{L}$ maka data berdistribusi normal dengan demikian dapat disimpulkan bahwa populasi kelompok $\mathrm{C}$ berdistribusi normal.

\section{d. Uji Normalitas Data Kuat Lentur Genteng Beton Untuk Perlakuan D (campuran $15 \%$ pasir abu batu).}

Hasil pengujian normalitas dari data nilai kuat lentur genteng beton dengan persentase substitusi pasir abu batu $10 \%$ menghasilkan $L_{0}=0,1372$, pada taraf signifikan $(\alpha)=0,01$ diperoleh nilai $L=0,2940$, dengan kriteria pengujian apabila $L_{0}<L$ maka data berdistribusi normal dengan demikian dapat disimpulkan bahwa populasi kelompok $\mathrm{D}$ berdistribusi normal.

\section{Uji Homogenitas Data}

Pengujian hogenitas dilakukan setelah persyaratan normalitas dipenuhi, pengujian homogenitas dilakukan dengan uji Bartlett. Data yang diuji adalah data kuat lentur dari masing-masing kelompok sampel. Dari perhitungan diperoleh $X^{2}$ hitung $=0,962$, jika taraf nyata $(\alpha)=0,01$ dari daftar Chi-Kuadrat dengan $\mathrm{dk}=9$ di dapat $\mathrm{X}_{\text {tabel }}^{2}=11,3$ sehingga $X^{2}{ }_{\text {hitung }}<X_{\text {tabel, }}^{2}$ maka dapat disimpulkan varians dari keempat kelompok homogen

Sedangkan untuk mengetahuai perbedaan kuat lentur genteng beton antar dua mean, maka digunakan analisis tes Schefee. Hasil perhitungan tes Schefee, dari perhitungan tersebut didapat $F(A-B)=2,352, F(A-C)=1,447$, $F(A-D)=4,523, F(B-C)=2,17, F(B-D)=5,246$ dan $F(C-D)=3,675$.

Dari data di atas dapat disimpulkan bahwa terdapat perbedaan yang signifikan terhadap kuat lentur rata-rata genteng beton yang menggunakan pasir abu batu yang persentase substitusi $0 \%$ dengan kuat lentur rata-rata yang persentase substitusi $15 \%$ dan 5\% dengan 15\%. Sedangkan untuk persentase substitusi $0 \%$ dengan $5 \%$, 0\% dengan 10\%, 5\% dengan 10\%,

Studi Penggunaan Abu Batu Sebagai Bahan Subtitusi Pasir Pada Pembuatan Genteng Beton Terhadap Kuat Lentur Genteng Beton ( Hendri Dunant Hamidi, Dosen Jurusan Teknik Sipil FT- UNJ.) 
$10 \%$ dengan $15 \%$ tidak terdapat perbedaan yang signifikan terhadap nilai kuat lentur rata-rata genteng beton.

\section{Pengujian Hipotesis}

Pengujian kuat lentur genteng beton yang menggunakan abu batu dengan persentase $0 \%, 5 \%, 10 \%$ dan $15 \%$, hipotesis nol $\left(\mathrm{H}_{0}\right)$ sebagai berikut : tidak ada perbedaan yang signifikan dari persentase penambahan abu batu terhadap nilai kuat lentur genteng beton.

Untuk mendapatkan hasil pengujian maka data penelitian dianalisa dengan menggunakan uji Analisis Varians (ANAVA) satu arah dengan taraf signifikan

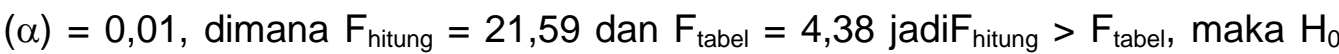
ditolak. Sehingga terbukti ada perbedaan yang signifikan dalam hal ini nilai kuat lentur genteng beton yang menggunakan abu batu dengan persentase substitusi $0 \%, 5 \%, 10 \%$ dan $15 \%$.

\section{Pembahasan Hasil Penelitian}

Terdapat perbedaan signifikan dalam hal kuat lentur yang menggunakan pasir abu batu sebagai bahan substitusi agregat halus dengan persentase perbandingan $0 \%, 5 \%, 10 \%$ dan $15 \%$. Dari hasil hasil penelitian menunjukan semakin banyak persentase yang penggunaan pasir abu batu, maka semakin rendah nilai kuat lenturnya. Dan semakin besar daya serap airnya. Dilihat dari masing-masing benda uji dilakukan memiliki keterkaitan antar sifat bahan, besaran butiran agregat, komposisi bahan, cara membuat dan merawat benda uji terhadap kekuatan lenturnya dan daya serap airnya.

Kuat lentur genteng beton yang menggunakan abu batu dengan persentase penambahan 5\% menghasilkan kuat lentur rata-rata $201 \mathrm{~kg} / \mathrm{cm}^{2}$, untuk persentase penambahan $10 \%$ menghasilkan kuat lentur rata-rata 189 $\mathrm{kg} / \mathrm{cm}^{2}$, untuk persentase substitusi $15 \%$ menghasilkan kuat lentur $172 \mathrm{~kg} / \mathrm{cm}^{2}$ sedangkan yang tanpa penambahan abu batu $(0 \%)$ menghasilkan kuat lentur rata-rata $197 \mathrm{~kg} / \mathrm{cm}^{2}$. Dengan demikian dengan bertambahnya persentase substitusi abu batu pada pembuatan genteng beton, maka kuat lentur rata-rata genteng beton yang dihasilkan semakin rendah. 


\section{Kesimpulan Dan Saran}

Berdasarkan hasil penelitian, maka dapat disimpulkan sebagai berikut :

1. Terdapat perbedaan nilai kuat lentur yang menggunakan abu batu sebagai bahan substitusi agregat halus dengan tingkat persentase 5\%, 10\% dan $15 \%$.

2. Substitusi pasir abu batu $5 \%$ pada genteng beton mampu meningkatkan nilai kuat lentur genteng beton yang melebihi kuat lentur kelas mutu I (200 $\mathrm{kg} / \mathrm{cm}^{2}$ ) yang disyaratkan SNI-03-0096-1999. Sedangkan substitusi pasir abu batu $10 \%$ dan $15 \%$ tidak memenuhi nilai kuat lentur kelas mutu I (200 $\left.\mathrm{kg} / \mathrm{cm}^{2}\right)$.

3. Besar persentase abu batu pada campuran genteng beton berpengaruh pada bobot genteng beton yang dihasilkan, semakin besar persentase abu batu pada campuran genteng beton, maka semakin ringan bobot genteng beton yang dihasilkan.

Dari data hasil pengujian daya serap air dapat disimpulkan bahwa semakin banyaknya persentase abu batu pada campuran genteng beton maka persentase penyerapan air genteng beton makin besar.

Berdasarkan pembahasan masalah dan kesimpulan, maka dapat dikemukakan beberapa saran yang perlu disampaikan antara lain :

1. Abu batu yang akan dipergunakan harus diayak terlebih dahulu karena gradasi pasir bervariasi yang nantinya akan berpengaruh terhadap tampak permukaan dan pori-pori genteng beton yang dihasilkan.

2. Untuk mendapatkan kekuatan dan keawetan pada genteng beton diusakan agar dalam proses pengadukan tidak terjadi pemisahan bahan-bahan penyusun genteng beton.

3. Perlu dilakukan penelitian lebih lanjut terhadap abu batu dengan batuan jenis lain yang cukup potensial untuk dijadikan bahan campuran pada pembuatan genteng beton.

4. Bagi mahasiswa lebih memperdalam pengetahuan mengenai ilmu bahan bangunan, sehingga dapat memperkaya ide dan inovasi mahasiswa untuk mengembangkan penelitian-penelitian yang lebih jauh lagi.

\footnotetext{
Studi Penggunaan Abu Batu Sebagai Bahan Subtitusi Pasir Pada Pembuatan Genteng Beton Terhadap Kuat Lentur Genteng Beton ( Hendri Dunant Hamidi, Dosen Jurusan Teknik Sipil FT- UNJ.)
} 


\section{Daftar Pustaka}

Arikunto, Suharsimi, Prosedur Penelitian suatu Pendekatan Praktek, Jakarta : Radar Jaya Offset, 1987.

Balai Penelitian Bahan, Petunjuk Praktis Proses Pembuatan Genteng Beton, Jakarta : Departemen Perindustrian, 1996.

Departemen Pekerjaan Umum, Persyaratan Umum Bahan Bangunan Indonesia, Jakarta : 1982.

Isparjadi, Statistika Pendidikan, Jakarta : Depdikbud, 1988.

Kardiono Tjokrodimulyo, Teknologi Beton, Yogyakarta : Nafiri, 1996.

Made, Sugiharta Hardira, Penambahan Abu Batu pada Campuran Beton dan Pengaruhnya terhadap Mutu Beton, Universitas Udayana, 1992

Randing, Penelitian Pengaruh Penambahan Serat ljuk pada Pembuatan Genteng Beton, Jurnal Pemukiman Vol. X No. 7-8, 1993.

SNI 03-0096-1995, Genteng Beton Mutu dan cara Uji, Dewan Standarisasi Nasional, 1995.

SNI 03-0096-1999, Genteng Beton, Dewan Standarisasi Nasional, 1999.

Sugianto Pandi, Studi Perbandingan Beton Mutu Tinggi dengan Menggunakan Abu Batu sebagai Pengganti Pasir, Universitas Tarumanegara, 1991 